\title{
Effect of physicians' smoking status on their knowledge, attitude, opinions and practices of smoking cessation in a University Hospital, in Egypt
}

Original

\author{
Nayera S. Mostafa, Mohamed Momen
}

Department of Community, Environmental and Occupational Medicine, Faculty of Medicine, Ain Shams University, Cairo, Egypt

\begin{abstract}
Background: The tobacco epidemic is one of the biggest public health threats. Smoking prevalence and smoking cessation intentions among physicians vary from a country/community to another. Recently, a global reduction in the rates of smoking among healthcare providers is observed.

Aim: This study aims to describe the effect of physicians' smoking status on their knowledge, attitude, opinions, and practices of smoking cessation in patients in a Tertiary Healthcare University Hospital in Cairo, Egypt.

Materials and Methods: A cross-sectional study was carried out at four specialized hospitals in a Tertiary Healthcare University Hospital in Cairo. Anonymous questionnaires included sociodemographic, occupational data, history of smoking, smoking-related knowledge, attitude, and practices of smoking cessation counselling.

Results: The study included 521 physicians, $26.5 \%$ of physicians have never received training on smoking-cessation approaches. The prevalence of current smoking among the studied physicians was $21.5 \%$. Only $45.5 \%$ of smoking physicians have never smoked in front of a patient and $27.7 \%$ have no compliance to the smoke-free policy in nonsmoking areas. Smoking physicians were significantly less likely than nonsmokers to identify the effect of passive smoking on the heart, lungs, and on neonates $(67.9,58.9$, and 53.6\% compared with $83.6,77,60$, and $56.7 \%$, respectively). A lower percentage of smoking physicians $(34.8 \%)$ agreed that smoking physicians are less likely to convince patients to quit smoking compared with about $60 \%$ of nonsmoking physicians. The practices related to smoking cessation as reported by both smokers and nonsmokers were inadequate.

Conclusion: Smoking status significantly affects the knowledge, attitude, and some practices of physicians related to smoking cessation counselling. Training on smoking cessation should be enforced during undergraduate and postgraduate studies of physicians.
\end{abstract}

Revceived: 16 February 2017, Accepted: 19 September 2017

Key Words: Practices, physicians, smoking cessation, university hospital.

Corresponding Author: Nayera Sami Mostafa, M.D., Community, Environmental and Occupational Medicine, Faculty of Medicine, Ain Shams University, Cairo, Egypt, Tel.: 00201005174443, E-mail: nayera_samy@lighttec.com.eg.

ISSN: 0013-2446, Vol. 92, No.2

\section{INTRODUCTION}

According to the $\mathrm{WHO}$, the tobacco epidemic is one of the biggest public health threats the world has ever faced, killing around six million people a year. More than five million of those deaths are the result of direct tobacco use, while more than 600000 are the result of nonsmokers being exposed to second-hand smoke. Nearly $80 \%$ of more than one billion smokers worldwide live in lowincome and middle-income countries, where the burden of tobacco-related illness and death is heaviest ${ }^{[1]}$. Smoking is a worldwide health risk where healthcare providers play a crucial role in preventing smoking by being a role model to smoking patients ${ }^{[2]}$.

Recently, a global reduction in the rates of smoking among healthcare providers is observed, while in some countries the rates of smoking among healthcare providers are as high as the general population ${ }^{[3]}$.

Smoking prevalence and smoking cessation intentions among physicians vary from a country/community to another. A review of studies carried out in developing countries and published through the years 1987-2010 showed that the highest smoking prevalence among physicians was in central eastern Europe $(37 \%)$, then Africa (29\%), central and south America (25\%) and the least was in Asia (17.5\%), being more prevalent with low quitting rates in developing countries than developed ones ${ }^{[4]}$. About $40 \%$ of the physicians participating in a study in Makkah mentioned that they spent 3-5 min counseling their patients about smoking ${ }^{[5]}$. Another study in Saudi Arabia have shown that $14.3 \%$ is the prevalence of current smoking among their study sample. Among those, 90\% were interested to quit smoking and $66 \%$ had actually tried 
before to quit. Those results represent a barrier in smoking cessation counselling ${ }^{[6]}$.

To our knowledge, there are no enough studies in Middle East and Egypt that investigated the effect of physicians' smoking status on patients' counseling for smoking cessation. This study aims to describe the effect of physicians' smoking status on their knowledge, attitude, opinions, and practices of smoking cessation with patients in a Tertiary Healthcare University Hospital in Cairo, Egypt.

\section{MATERIALS AND METHODS}

The present study is a cross-sectional one that included physicians from four departments specialized in a Tertiary Healthcare University Hospital in Cairo, Egypt. Those Departments are Internal Medicine, Surgery (including different specialties of internal medicine and surgery), Pediatrics, Dermatology, and Gynecology and Obstetrics.

A sample of 312 calculated using smoking prevalence among physicians in Africa ${ }^{[4]}$ equals to $29 \pm 5 \%$ and $95 \%$ confidence interval. The sample was calculated using the Epi Info 2002 program ( Centers for Disease Control and Prevention, Atlanta, Georgia, US). The sample was increased to reach 512 participants and collected as a convenience one. Equal number of participants was targeted from each department, but practically, data collection faced some obstacles due to the workload or uncooperation of some staff members. So, the final number of participants was not equal.

The data collection tool was based on the instruments developed by previous similar studies ${ }^{[7,8]}$. Data were collected at the beginning of 2016 by means of an anonymous questionnaire (consisted of 44 questions) targeting information about sociodemographic and occupational data (age, sex, specialty, years of medical experience, previous training on smoking cessation), smoking status and history of smoking (type and frequency of smoking, starting age, previous quitting attempts). In addition, smoking-related knowledge (health hazards of active and passive smoking) was asked about using (correct/incorrect/do not know responses), attitude (agree/ disagree/unsure), and practices of smoking cessation counselling (always, sometimes, rarely, never). Current smoker includes any smoker even occasional ones, while former smokers are those who quit smoking at least 1 year ago.

\section{Ethical considerations}

Approval was obtained from the Research Ethics Committee and consent from the participants after explaining the study rationale and purpose to the study participants, and ensuring them confidentiality of data.

\section{Statistical analysis}

Data were coded, verified, and analyzed using the statistical package for the social sciences (SPSS), version 20 (IBM Corp., New York, New York, USA) ${ }^{[9]}$. The study participants were divided into two groups 'current smokers' and 'nonsmokers'. The nonsmokers group included never smokers and those who quitted smoking because the latter group was relatively small in number to avoid obstacles in analysis and data presentation.

Descriptive statistics included frequency and percentage for non-numerical data. $\chi 2$ was used as the test of significance with a P-value of less than 0.05 considered to be statistically significant.

\section{RESULTS}

The current study included 521 physicians (335 men and 186 women) with $68.1 \%$ below 30 years of age. More than half of the studied sample $(58.7 \%)$ had no postgraduate degree. The studied group was recruited from different specialties of the university hospital; $35.3 \%$ from surgery, $29.8 \%$ from internal medicine, $13.1 \%$ from pediatrics, $12.5 \%$ from gynecology, $6.1 \%$ from dermatology, and house officers represent $3.2 \%$ of the sample. The majority of the studied physicians $(62.2 \%)$ practiced in the medical field for less than 5 years. The prevalence of current smoking among the studied physicians was $21.5 \%$, while $8.3 \%$ quitted smoking, and $70.2 \%$ never smoked. Additionally, $26.5 \%$ of physicians had no training on smoking-cessation approaches; only $32.4 \%$ had formal training during medical school; $20.9 \%$ had formal training during specialization programs; and $20.2 \%$ had training through special conferences, symposia, or workshops (Fig. 1).

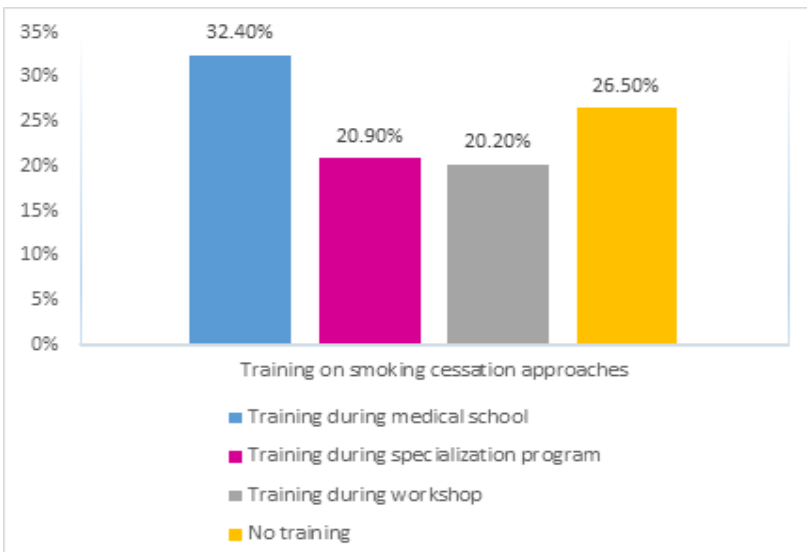

Fig. 1: Timing and vehicle of training on smoking cessation received by the studied physicians 
There was a statistically significant difference in smoking status as regards sex, age, and latest education where $29.9 \%$ of current smokers was men compared with only $6.5 \%$ among women $(P<0.001)$. Also, the majority of current smokers were among the age groups of between 30 and 45 years and more than 45 years (38.3 and $30.4 \%$, respectively) compared with only $14.6 \%$ among the age group of less than 30 years $(P<0.001)$. Additionally, the higher percent of current smokers were among physicians with master's and MD degrees (31.0 and $28.8 \%$, respectively) compared with only $15.4 \%$ among physicians with only bachelor's degree $(P<0.001)$. There was no statistically significant difference in smoking status by specialty (Table 1).

Table 1: Distribution of physicians according to their smoking status, University Hospital in Cairo, Egypt, 2016

\begin{tabular}{|c|c|c|c|c|c|}
\hline & \multicolumn{2}{|c|}{ Physicians } & \multirow{2}{*}{$\begin{array}{l}\text { Total } \\
(\mathrm{n}=521) \\
\text { No. }(\%)\end{array}$} & \multicolumn{2}{|c|}{ Test of significance } \\
\hline & $\begin{array}{c}\text { Non-smokers } \\
(\mathrm{n}=409) \\
\text { No.(\%) }\end{array}$ & $\begin{array}{l}\text { Current Smokers } \\
(\mathrm{n}=112) \\
\text { No. }(\%)\end{array}$ & & $X^{2}$ & $\mathrm{p}$ \\
\hline $\begin{array}{l}\text { Gender } \\
\text { Male } \\
\text { Female }\end{array}$ & $\begin{array}{l}235(70.1) \\
174(93.5)\end{array}$ & $\begin{array}{c}100(29.9) \\
12(6.5)\end{array}$ & $\begin{array}{l}335(64.3) \\
186(35.7)\end{array}$ & 38.802 & 0.000 \\
\hline $\begin{array}{l}\text { Age (years) } \\
<30 \\
30-45 \\
>45\end{array}$ & $\begin{array}{l}303(85.4) \\
74(61.7) \\
32(69.6)\end{array}$ & $\begin{array}{l}52(14.6) \\
46(38.3) \\
14(30.4)\end{array}$ & $\begin{array}{c}355(68.1) \\
120(23.1) \\
46(8.8)\end{array}$ & 32.202 & 0.000 \\
\hline $\begin{array}{l}\text { Latest education } \\
\text { Bachelor } \\
\text { Master } \\
\text { MD }\end{array}$ & $\begin{array}{c}259(84.6) \\
98(69) \\
52(71.2)\end{array}$ & $\begin{array}{c}47(15.4) \\
44(31) \\
21(28.8)\end{array}$ & $\begin{array}{c}306(58.7) \\
142(27.3) \\
73(14)\end{array}$ & 16.693 & 0.000 \\
\hline $\begin{array}{l}\text { Specialty } \\
\text { Surgery } \\
\text { Internal Medicine } \\
\text { Dermatology } \\
\text { Gynecology } \\
\text { Pediatric } \\
\text { House officer }\end{array}$ & $\begin{array}{l}136(73.9) \\
122(78.7) \\
27(84.4) \\
49(75.4) \\
61(89.7) \\
14(82.4)\end{array}$ & $\begin{array}{c}48(26.1) \\
33(21.3) \\
5(15.6) \\
16(24.6) \\
7(10.3) \\
3(17.6)\end{array}$ & $\begin{array}{l}184(35.3) \\
155(29.7) \\
32(6.1) \\
65(12.5) \\
68(13.1) \\
17(3.3)\end{array}$ & 8.536 & 0.128 \\
\hline
\end{tabular}

Regarding the distribution of smoker physicians according to their smoking habits, the majority of them $(52.7 \%)$ started to smoke at the age of between 20 and 30 years with $69.6 \%$ having smoked on a daily basis and $33.0 \%$ of them had $5-10$ years of smoking. The highest percentage (31.3\%) used to smoke less than five cigarettes per day. Only $45.5 \%$ of smoking physicians have never smoked in front of a patient; $70.5 \%$ have smoked during shift; and $27.7 \%$ have no compliance to the smoke-free policy in nonsmoking areas. The reasons to smoke for most of them were to reduce/relieve work-related stress and improve sociability among peers ( 66.1 and $48.2 \%$, respectively). Only $45.5 \%$ have attempted to quit smoking and the most common reasons for not trying to quit were fear of loss of way to handle stress and cravings (52.7 and $50.9 \%$, respectively). However, most of the studied group $(77 \%)$ thought that their tobacco use has negatively affected their health in any way (Table 2). 
Table 2: Distribution of smoker physicians according to their smoking habits, University Hospital in Cairo, Egypt, 2016

\begin{tabular}{|c|c|}
\hline Characteristics & $\begin{array}{c}\text { Smoking physicians }(\mathrm{n}=112) \\
\text { No. }(\%)\end{array}$ \\
\hline $\begin{array}{l}\text { Age of smoking start (years) } \\
\quad<20 \\
\quad 20-30 \\
>30 \\
\text { Mean } \pm \text { SD }\end{array}$ & $\begin{array}{c}44(39.3) \\
59(52.7) \\
9(8) \\
22 \pm 5\end{array}$ \\
\hline $\begin{array}{l}\text { Frequency of smoking } \\
\text { Occasionally } \\
\text { Up to } 3 \text { times a week } \\
\text { 4-5 times a week } \\
\text { Daily }\end{array}$ & $\begin{aligned} 17 & (15.2) \\
5 & (4.5) \\
12 & (10.7) \\
78 & (69.6)\end{aligned}$ \\
\hline $\begin{array}{l}\text { Estimated no. of cigarettes smoked per day } \\
\quad<5 \\
\quad 5-10 \\
11-15 \\
16-20 \\
>20\end{array}$ & $\begin{array}{c}35(31.3) \\
32(28.6) \\
29(25.9) \\
12(10.7) \\
4(3.6)\end{array}$ \\
\hline $\begin{array}{l}\text { Frequency of smoking in front of patient } \\
\text { Never } \\
\text { Rarely } \\
\text { Sometimes } \\
\text { Always } \\
\text { Smoking during shift } \\
\text { Good compliance to smoke-free policy } \\
\text { Attempted to quit smoking } \\
\text { Succeeded to quit smoking }\end{array}$ & $\begin{array}{l}51(45.5) \\
31(27.7) \\
28(25) \\
2(1.8) \\
79(70.5) \\
81(72.3) \\
51(45.5) \\
9(8.3)\end{array}$ \\
\hline $\begin{array}{l}\text { Reason for smoking } \\
\text { It reduces/relieves stress-related work } \\
\text { It improves sociability among peers } \\
\text { It enhances memory and alertness } \\
\text { It improves skills and performance } \\
\text { It keeps my weight down }\end{array}$ & $\begin{array}{l}74(66.1) \\
54(48.2) \\
36(32.1) \\
28(25) \\
23(20.5)\end{array}$ \\
\hline $\begin{array}{l}\text { Reasons for NOT trying to quit smoking } \\
\text { Fear of loss of way to handle stress } \\
\text { Cravings } \\
\text { Fear of nicotine withdrawal symptom } \\
\text { Discouragement from previous failure to quit smoking } \\
\text { Fear of risk of gaining weight } \\
\text { Fear of loss of social relations } \\
\text { The high cost of medicines used for quitting }\end{array}$ & $\begin{array}{l}59(52.7) \\
57(50.9) \\
45(40.2) \\
36(32.1) \\
16(14.3) \\
14(12.5) \\
12(10.7)\end{array}$ \\
\hline $\begin{array}{l}\text { Tobacco use negatively affect health } \\
\text { No } \\
\text { Yes } \\
\text { Not sure }\end{array}$ & $\begin{array}{c}8(7.1) \\
75(77) \\
29(25.9)\end{array}$ \\
\hline
\end{tabular}


Regarding the knowledge of studied physicians toward smoking, nonsmokers have better knowledge. It is shown in Table 4 that higher percentages of nonsmokers had correct knowledge about the effects of active and passive smoking on lungs and heart diseases of both adults and children ( $\mathrm{P}$ value shows statistical difference). More nonsmokers also had correct knowledge about the risk of passive smoking to children's health regarding lower respiratory tract illnesses $(\mathrm{P}=0.016)$ and neonatal death $(\mathrm{P}=0.013)$. About $72 \%$ of nonsmokers, as well, agreed that maternal smoking during pregnancy increases the risk of sudden infant death syndrome compared with $54.5 \%$ of smokers $(P=0.002)$ (Table 3).

Table 3: Knowledge of physicians hazards of smoking in relation to their smoking status, University Hospital in Cairo, Egypt, 2016

\begin{tabular}{|c|c|c|c|c|c|}
\hline \multirow[b]{2}{*}{ Knowledge } & \multicolumn{2}{|c|}{ Physicians } & \multirow[b]{2}{*}{$\begin{array}{l}\text { Total } \\
(\mathrm{n}=521) \\
\text { No. }(\%)\end{array}$} & \multicolumn{2}{|c|}{ Test of significance } \\
\hline & $\begin{array}{c}\text { Non-smokers } \\
(\mathrm{n}=409) \\
\text { No.(\%) }\end{array}$ & $\begin{array}{l}\text { Current Smokers } \\
\qquad(\mathrm{n}=112) \\
\text { No. }(\%)\end{array}$ & & $\mathrm{X}^{2}$ & $\mathrm{P}$ \\
\hline \multicolumn{6}{|c|}{ Active smoking increases the risk of ischemic heart disease among smokers } \\
\hline $\begin{array}{l}\text { Correct } \\
\text { Don't know } \\
\text { Incorrect }\end{array}$ & $\begin{array}{c}342(83.6) \\
66(16.1) \\
1(0.2)\end{array}$ & $\begin{array}{c}76(67.9) \\
36(32.1) \\
0\end{array}$ & $\begin{array}{c}418(80.2) \\
102(19.6) \\
1(0.2)\end{array}$ & 14.502 & $0.001^{*}$ \\
\hline \multicolumn{6}{|c|}{ Passive smoking increases the risk of lung disease in non-smoking adults } \\
\hline $\begin{array}{l}\text { Correct } \\
\text { Don't know } \\
\text { Incorrect }\end{array}$ & $\begin{array}{c}315(77) \\
93(22.7) \\
1(0.2)\end{array}$ & $\begin{array}{c}66(58.9) \\
45(40.2) \\
1(0.9)\end{array}$ & $\begin{array}{c}381(73.1) \\
138(26.5) \\
2(0.4)\end{array}$ & 14.993 & $0.001^{*}$ \\
\hline \multicolumn{6}{|c|}{ Passive smoking increases the risk of heart disease in non-smoking adults. } \\
\hline $\begin{array}{l}\text { Correct } \\
\text { Don't know } \\
\text { Incorrect }\end{array}$ & $\begin{array}{c}246(60.1) \\
151(36.9) \\
12(2.9)\end{array}$ & $\begin{array}{l}52(46.4) \\
56(50) \\
4(3.6)\end{array}$ & $\begin{array}{c}298(57.2) \\
207(39.7) \\
16(3.1)\end{array}$ & 6.796 & $0.031^{*}$ \\
\hline \multicolumn{6}{|c|}{ Passive smoking increases the risk of lower respiratory tract illnesses in exposed children. } \\
\hline $\begin{array}{l}\text { Correct } \\
\text { Don't know } \\
\text { Incorrect }\end{array}$ & $\begin{array}{c}285(69.7) \\
118(28.9) \\
6(1.5)\end{array}$ & $\begin{array}{l}62(55.4) \\
47(42) \\
3(2.7)\end{array}$ & $\begin{array}{c}347(66.6) \\
165(31.7) \\
9(1.7)\end{array}$ & 8.23 & $0.016^{*}$ \\
\hline \multicolumn{6}{|c|}{ Neonatal death is associated with passive smoking } \\
\hline $\begin{array}{l}\text { Correct } \\
\text { Don't know } \\
\text { Incorrect }\end{array}$ & $\begin{array}{c}232(56.7) \\
150(36.7) \\
27(6.6)\end{array}$ & $\begin{array}{l}47(42) \\
58(51.8) \\
7(6.3)\end{array}$ & $\begin{array}{c}279(53.6) \\
208(39.9) \\
34(6.5)\end{array}$ & 8.512 & $0.013^{*}$ \\
\hline \multicolumn{6}{|c|}{ Maternal smoking during pregnancy increases the risk of sudden infant death syndrome } \\
\hline $\begin{array}{l}\text { Correct } \\
\text { Don't know } \\
\text { Incorrect }\end{array}$ & $\begin{array}{l}294(71.9) \\
108(26.4) \\
7(1.7)\end{array}$ & $\begin{array}{c}61(54.5) \\
49(43.8) \\
2(1.8)\end{array}$ & $\begin{array}{c}355(68.1) \\
157(30.1) \\
9(1.7)\end{array}$ & 12.695 & 0.002 \\
\hline
\end{tabular}

\footnotetext{
*: Significant at $p<0.05$
} 
Regarding the attitude of the studied physicians toward smoking, the majority of nonsmokers $(80.2 \%)$ believed that health professionals should set a good example by not smoking compared with $55.4 \%$ of smokers $(P<0.001)$. However, $60.9 \%$ of nonsmokers thought that patient's chances of quitting smoking are increased if a health professional advises him or her to quit compared with $48.2 \%$ of smokers $(P=0.039)$. Additionally, most of nonsmoking physicians agreed that health professionals should routinely ask about their patients smoking habits and should routinely advise their patients to quit smoking (77.8 and $77 \%$, respectively) compared with (55.4 and $56.3 \%$, respectively) of smokers $(P<0.001)$. However, $59.9 \%$ of nonsmokers agree that health professionals who smoke are less likely to advise people to stop smoking compared with $34.8 \%$ of smokers $(P<0.001$, Table 4$)$.

Table 4: Attitude of physicians towards smoking cessation in relation to their smoking status, University Hospital in Cairo, Egypt, 2016

\begin{tabular}{|c|c|c|c|c|c|}
\hline & \multicolumn{2}{|c|}{ Physicians } & \multirow[b]{2}{*}{$\begin{array}{l}\text { Total } \\
(n=521) \\
\text { No. }(\%)\end{array}$} & \multicolumn{2}{|c|}{ Test of significance } \\
\hline & $\begin{array}{l}\text { Non-smokers } \\
(\mathrm{n}=409) \\
\text { No. }(\%)\end{array}$ & $\begin{array}{l}\text { Current Smokers } \\
(\mathrm{n}=112) \\
\text { No. }(\%)\end{array}$ & & $\mathrm{X}^{2}$ & $\mathrm{P}$ \\
\hline \multicolumn{6}{|c|}{ Health professionals should set a good example by not smoking } \\
\hline $\begin{array}{l}\text { Agree } \\
\text { Unsure } \\
\text { Disagree }\end{array}$ & $\begin{array}{c}328(80.2) \\
75(18.3) \\
6(1.5)\end{array}$ & $\begin{array}{c}62(55.4) \\
41(36.6) \\
9(8)\end{array}$ & $\begin{array}{c}390(74.8) \\
116(22.3) \\
15(2.9)\end{array}$ & 33.604 & $0.000 *$ \\
\hline \multicolumn{6}{|c|}{ Patient's chances of quitting smoking are increased if a health professional advises him or her to quit } \\
\hline $\begin{array}{l}\text { Agree } \\
\text { Unsure } \\
\text { Disagree }\end{array}$ & $\begin{array}{c}249(60.9) \\
137(33.5) \\
23(5.6)\end{array}$ & $\begin{array}{c}54(48.2) \\
52(46.4) \\
6(5.4)\end{array}$ & $\begin{array}{c}303(58.1) \\
189(36.3) \\
29(5.6)\end{array}$ & 6.49 & $0.039 *$ \\
\hline \multicolumn{6}{|c|}{ Health professionals should routinely ask about their patients smoking habits } \\
\hline $\begin{array}{l}\text { Agree } \\
\text { Unsure } \\
\text { Disagree }\end{array}$ & $\begin{array}{c}318(77.8) \\
86(21) \\
5(1.2)\end{array}$ & $\begin{array}{c}62(55.3) \\
47(42) \\
3(2.7)\end{array}$ & $\begin{array}{c}380(73) \\
133(25.5) \\
8(1.5)\end{array}$ & 22.358 & $0.039 *$ \\
\hline \multicolumn{6}{|c|}{ Heath professionals should routinely advise their patients to quit smoking } \\
\hline $\begin{array}{l}\text { Agree } \\
\text { Unsure } \\
\text { Disagree }\end{array}$ & $\begin{array}{c}315(77) \\
86(21) \\
8(2)\end{array}$ & $\begin{array}{c}63(56.2) \\
47(42) \\
2(1.8)\end{array}$ & $\begin{array}{c}378(72.6) \\
133(25.5) \\
10(1.9)\end{array}$ & 20.338 & $0.000^{*}$ \\
\hline \multicolumn{6}{|c|}{ Health professionals who smoke are less likely to advise people to stop smoking } \\
\hline $\begin{array}{l}\text { Agree } \\
\text { Unsure } \\
\text { Disagree }\end{array}$ & $\begin{array}{c}245(59.9) \\
117(28.6) \\
47(11.5)\end{array}$ & $\begin{array}{l}39(34.8) \\
59(52.7) \\
14(12.5)\end{array}$ & $\begin{array}{r}284(54.5) \\
176(33.8) \\
61(11.7)\end{array}$ & 25.305 & $0.000 *$ \\
\hline
\end{tabular}

\footnotetext{
*: Significant at $p<0.05$
}

Regarding the reported practices of smoking-cessation counseling, practices in both groups were inadequate. Nonsmokers showed poor practices regarding explaining the consequences of smoking on health and teaching patients about methods of quitting. The difference between both groups were nonsignificant $(P>0.05$, Table 5$)$. 
Table 5: Reported practice of physicians regarding smoking cessation counseling in relation to their smoking status, University Hospital, Cairo, Egypt, 2016

\begin{tabular}{|c|c|c|c|c|c|}
\hline & \multicolumn{2}{|c|}{ Physicians } & \multirow[b]{2}{*}{$\begin{array}{c}\text { Total } \\
(\mathrm{n}=521) \\
\text { No. }(\%)\end{array}$} & \multicolumn{2}{|c|}{ Test of significance } \\
\hline & $\begin{array}{l}\text { Non-smokers } \\
(\mathrm{n}=409) \\
\text { No. }(\%)\end{array}$ & $\begin{array}{l}\text { Current Smokers } \\
\quad(\mathrm{n}=112) \\
\text { No. }(\%)\end{array}$ & & $\mathrm{X}^{2}$ & $P$ \\
\hline \multicolumn{6}{|c|}{ I ask patients if they smoke } \\
\hline $\begin{array}{l}\text { Never } \\
\text { Rarely } \\
\text { Sometimes } \\
\text { Always }\end{array}$ & $\begin{array}{c}29(7.1) \\
33(8.1) \\
113(27.6) \\
234(57.2)\end{array}$ & $\begin{array}{c}10(8.9) \\
8(7.1) \\
41(36.6) \\
53(47.3)\end{array}$ & $\begin{array}{c}39(7.5) \\
41(7.9) \\
154(29.5) \\
287(55.1)\end{array}$ & 4.502 & 0.216 \\
\hline \multicolumn{6}{|c|}{ I explain to my patients the consequences of smoking on one's health } \\
\hline $\begin{array}{l}\text { Never } \\
\text { Rarely } \\
\text { Sometimes } \\
\text { Always }\end{array}$ & $\begin{array}{c}30(7.3) \\
39(9.5) \\
164(40.1) \\
176(43.1)\end{array}$ & $\begin{array}{c}8(7.1) \\
5(4.5) \\
39(34.8) \\
60(53.6)\end{array}$ & $\begin{array}{c}38(7.3) \\
44(8.4) \\
203(39) \\
236(45.3)\end{array}$ & 5.466 & 0.14 \\
\hline \multicolumn{6}{|c|}{ I encourage/challenge my patients to quit smoking } \\
\hline $\begin{array}{l}\text { Never } \\
\text { Rarely } \\
\text { Sometimes } \\
\text { Always }\end{array}$ & $\begin{array}{c}27(6.6) \\
40(9.8) \\
139(34) \\
203(49.6)\end{array}$ & $\begin{array}{c}11(9.8) \\
16(14.3) \\
37(33) \\
48(42.9)\end{array}$ & $\begin{array}{c}38(7.3) \\
56(10.7) \\
176(33.8) \\
251(48.2)\end{array}$ & 3.772 & 0.289 \\
\hline \multicolumn{6}{|c|}{ I teach my patients possible methods on how to quit smoking } \\
\hline $\begin{array}{l}\text { Never } \\
\text { Rarely } \\
\text { Sometimes } \\
\text { Always }\end{array}$ & $\begin{array}{c}57(13.9) \\
109(26.7) \\
131(32) \\
112(27.4)\end{array}$ & $\begin{array}{l}15(13.4) \\
22(19.6) \\
36(32.2) \\
39(34.8)\end{array}$ & $\begin{array}{c}72(13.8) \\
131(25.1) \\
167(32.1) \\
151(29)\end{array}$ & 3.414 & 0.333 \\
\hline \multicolumn{6}{|c|}{ Interventions do you use to help your patients stop smoking } \\
\hline $\begin{array}{l}\text { Counselling only } \\
\text { Traditional remedies } \\
\text { Self- help materials } \\
\text { Medications }\end{array}$ & $\begin{array}{c}274(67) \\
86(21) \\
166(40.6) \\
148(36.2)\end{array}$ & $\begin{array}{l}68(60.7) \\
17(15.2) \\
44(39.3) \\
29(25.9)\end{array}$ & $\begin{array}{c}342(65.6) \\
103(19.8) \\
210(40.3) \\
177(34)\end{array}$ & 6.225 & $0.000^{*}$ \\
\hline
\end{tabular}

*: Significant at $p<0.05$

Regarding the opinions of physicians about the effects of smoking status of physicians on smoking-cessation counseling practices, $38.1 \%$ of nonsmoking physicians thought that smoking affects the way they counsel their patients to quit smoking in comparison to only $29.5 \%$ among smoking physicians $(P<0.001)$. In addition, $72.6 \%$ of nonsmoking physicians thought that it is less likely to convince patients to quit smoking if the counselor is a smoker in comparison to only $30.4 \%$ among smoking physicians $(P<0.001$, Table 6). 
Table 6: Physicians' opinions of effects of smoking status of physicians on smoking-cessation counseling

\begin{tabular}{|c|c|c|c|c|c|}
\hline & \multicolumn{2}{|c|}{ Physicians } & \multirow[b]{2}{*}{$\begin{array}{c}\text { Total } \\
(\mathrm{n}=521) \\
\text { No. }(\%)\end{array}$} & \multicolumn{2}{|c|}{ Test of significance } \\
\hline & $\begin{array}{l}\text { Non-smokers } \\
\qquad \begin{array}{l}(\mathrm{n}=409) \\
\text { No }(\%)\end{array}\end{array}$ & $\begin{array}{l}\text { Current Smokers } \\
\qquad \begin{array}{c}(\mathrm{n}=112) \\
\text { No }(\%)\end{array}\end{array}$ & & $\mathrm{X}^{2}$ & $P$ \\
\hline \multicolumn{6}{|c|}{ Does (your) smoking affect the way you counsel your patients to quit smoking? } \\
\hline $\begin{array}{l}\text { No } \\
\text { Yes } \\
\text { Not sure }\end{array}$ & $\begin{array}{c}60(14.7) \\
156(38.1) \\
193(47.2)\end{array}$ & $\begin{array}{c}37(33) \\
33(29.5) \\
42(37.5)\end{array}$ & $\begin{array}{l}97(18.6) \\
189(36.3) \\
235(45.1)\end{array}$ & 19.584 & $0.000 *$ \\
\hline
\end{tabular}

Are you less likely to convince patients to quit smoking if you are a smoker?

$\begin{array}{lccc}\text { No } & 47(11.5) & 16(14.3) & 63(12.1) \\ \text { Yes } & 297(72.6) & 34(30.4) & 331(63.5) \\ \text { Not sure } & 65(15.9) & 62(55.4) & 127(24.4)\end{array}$

Does counseling on direct health harms of smoking helps with smoking cessation among your patients?

$\begin{array}{lcccc}\text { No } & 56(13.7) & 29(25.9) & 85(16.3) & \\ \text { Yes } & 275(67.2) & 52(46.4) & 327(62.8) & \\ \text { Not sure } & 78(19.1) & 31(27.7) & 109(20.9) & 17.202\end{array}$

Does counseling on health harms of passive smoking helps with smoking cessation among your patients?

\begin{tabular}{|c|c|c|c|c|c|}
\hline No & $50(12.2)$ & $14(2.5)$ & $64(12.3)$ & & \\
\hline Yes & $253(61.9)$ & $54(48.2)$ & $307(58.9)$ & & \\
\hline Not sure & $106(25.9)$ & $44(39.3)$ & $150(28.8)$ & 8.241 & $0.016^{*}$ \\
\hline
\end{tabular}

Do you think counseling family members of your patients on health harms of second hand smoke helps with their smoking cessation?

\begin{tabular}{|c|c|c|c|c|c|}
\hline No & $39(9.5)$ & $14(12.5)$ & $53(10.2)$ & & \\
\hline Yes & $236(57.7)$ & $48(42.9)$ & $284(54.5)$ & & \\
\hline
\end{tabular}

*: Significant at $p<0.05$

\section{DISCUSSION}

The frequency of current smokers among physicians in the present study is $21.5 \%$ where $29.9 \%$ of male physicians and $6.5 \%$ of female physicians were current smokers. Those rates were higher than a study in Kasr Elaini Hospitals which stated that the prevalence of current smoking among male physicians was $12.4 \%$ and less than $1 \%$ among female physicians ${ }^{[10]}$. Another study carried out in Bahrain has shown that $8.6 \%$ of the studied physicians were smokers $(20.0 \%$ among men and $3.0 \%$ among women). The low frequency of smoking among women is attributed to the cultural factors in the Middle East community where female smoking is considered a stigma $^{[11]}$. Almost $15 \%$ of smokers are daily smokers (70\% of the whole studied population were daily smokers), while in Bahrain $2.1 \%$ of the physicians smoked daily ${ }^{[1]}$. Among current cigarette smokers, the mean initiation age was 22 years and the average number of cigarettes smoked per day was 15 .
Discrepancies are shown between the frequency of smoking among male physicians in the current study and other studies: Canada $(8 \%)^{[12]}$, Switzerland $(12.6 \%)^{[13]}$ and Japan $(16.2 \%)^{[14]}$. This can be explained by the difference in the definition of smoking where our study includes smokers even occasionally, while those studies included only daily smokers.

This rate is close to that reported among the general population in Alexandria $(27.2 \%)^{[15]}$. While it is much less than the prevalence of current smokers reported among physicians in Urban Family Medicine Centers in Alexandria (51.1\%) [7], it is higher than the rate reported among family practice centers in Suez Canal $(5.3 \%)^{[16]}$. The low rate of the last study may be explained by its small sample size.

The prevalence of smoking among physicians varies worldwide from $28.3 \%$ among Italian general practitioners in $2000^{[17]}$ to $63 \%$ among Russian male physicians and $12 \%$ of women ${ }^{[18]}$, while in Japan it was $27.1 \%$ for men 
and $6.8 \%$ for women ${ }^{[19]}$. A study conducted among family medicine physicians and nurses in Bosnia and Herzegovina in 2002 showed that $\sim 45 \%$ of the studied sample were currently smoking ${ }^{[20]}$.

The current study has shown that $73.5 \%$ of the studied sample had previous training on smoking cessation approaches whether during medical schools, specialization programs, conferences, or during workshops. This figure is compared with only $30 \%$ of primary healthcare personnel in Alexandria ${ }^{[7]}$, and $50 \%$ of nurses and $43 \%$ of doctors in Bosnia $^{[20]}$. At the same time, the current study showed that the correct knowledge about health risks of both active and passive smoking ranges from 53.6 to $80.2 \%$ and 19.6 to $39.9 \%$ of the studied sample were unsure about the correct answers, respectively. This reflects the need of applying a more effective training on smoking cessation approaches.

A study in Kasr Elaini Hospitals has shown that $90 \%$ of the healthcare providers included in their study (physicians, nurses, and employees) correctly responded that passive smoking is a significant cause of tobacco-related diseases' with significant difference between smokers and nonsmokers (who have better knowledge $)^{[10]}$. Nearly $80 \%$ of nonsmoking physicians and $55 \%$ of currently smoking ones agreed that health professionals should set a good example by not smoking. A positive attitude is more prevalent among nonsmokers. Fifty-five percent of smoking physicians had never smoked in front of patients. In Alexandria, $45.5 \%$ of their sample had a negative attitude that smoking is a personal matter and can be performed at any time and place $\mathrm{e}^{[7]}$.

The current study has shown that nearly $58 \%$ of the studied sample $(60.9 \%$ of nonsmokers and about $48 \%$ of current smokers) agreed that patient's chances of quitting smoking are increased if a health professional advises him or her to quit. In Alexandria, almost similar results were mentioned, $65 \%$ of the healthcare personnel $(71 \%$ of nonsmokers and $57 \%$ of smokers) ${ }^{[7]}$. In the present study, $45.5 \%$ had attempted before to quit smoking and $8.3 \%$ had successfully quitted it. The willingness to quit $(70 \%)$ is much higher than the attempt to quit (46\%) as reported by Ashton and Streem ${ }^{[21]}$. In Asia, more than $84 \%$ of current smokers wanted to quit, and $74.7 \%$ had made a recent serious attempt to do so ${ }^{[22]}$. In Armenia and China, smokers were less likely to counsel patients to quit ${ }^{[23,24]}$.

Healthcare workers are generally foreseen to be role models to the surrounding population. Special concerns are given to their lifestyle, such as nutrition, exercise, and smoking status ${ }^{[25]}$. In the present study, $75 \%$ of the studied sample agreed that health professionals should set a good example by not smoking. This proportion was higher than that reported in Alexandria $(56.4 \%)^{[7]}$.

Inquiring about smoking cessation practices in the present study, it was shown that $92.7 \%$ of the studied sample explained to their patients the consequences of smoking on one's health; of them $45.3 \%$ always do that. In addition, $48.2 \%$ of the sample were always encouraging their patients to quit smoking. On the contrary, the results obtained from a study carried out in Alexandria showed that $64.1 \%$ of primary healthcare workers were routinely advising their smoking patients to quit smoking ${ }^{[7]}$. This difference may be explained by the fact that the sample in Alexandria included nurses (in addition to physicians) who have more time for giving health education messages, unlike physicians. About $85 \%$ of the physicians in our study claimed that they always or sometimes asked their patients about their smoking status. In Suez canal ${ }^{[16]}$ and El-Kasr El-Aini Hospital ${ }^{[10]}$ in Egypt, 60 and 70\%, respectively, asked about the patients' smoking status, while 36 and $74 \%$, respectively advised patients to stop smoking. In a British study ${ }^{[26]}$, physicians had a positive attitude toward advising patients to quit.

A Russian study stated that health professionals who are smokers are less likely to share in smoking cessation activities or campaigns ${ }^{[18]}$. This supports the results of the present study, where $54.5 \%$ agreed that health professionals who smoke are less likely to advise people to stop smoking. This result is much less than that obtained in Alexandria $(81.4 \%)^{[7]}$.

The WHO stated that every health professional should play a role in smoking cessation, for example, asking about tobacco use, assessing willingness to quit, advising quitting, and further referring and arranging for cessation services $^{[25]}$.

Hazards of both active and passive smoking are well perceived by nonsmokers than smokers in the current study $(P<0.001)$. Similarly, an Egyptian study has shown that nonsmokers had better perception for smoking hazards ${ }^{[27]}$. In general, nonphysician population, nonsmokers perceive hazards of smoking better than smokers $^{[28]}$.

About $55 \%$ of smoking physicians in the current study admitted that they smoke in front of the patient. Similarly, $51 \%$ of smoker physicians in Senegal reported smoking in front of them ${ }^{[29]}$.

About half $(45.5 \%)$ of the smoking physicians have attempted quitting smoking before. A similar study carried out in 1997 among physicians of the same hospitals showed higher rate $(66 \%)^{[30]}$.

Most of the study group (74.9\%) believe that 'Health professionals should set a good example by not smoking', while only $58 \%$ agreed that 'patient's chances of quitting smoking are increased if a health professional advises him or her to quit'. On the contrary, a study in Bosnia and Herzegovina, showed better results, where $80 \%$ of the interviewed physicians and nurses agreed with the previous two statements ${ }^{[20]}$.

\section{LIMITATIONS OF STUDY}

The sample chosen in this study did not consider randomization; hence, generalization of the results is 
incorrect. In addition, targeting more than one hospital might provide a broader description of physicians regarding smoking cessation counselling in the country. Some designed questions probably were leading or adversely biased by recall.

\section{CONCLUSION}

Smoking status significantly affect knowledge, attitude, and some practices of smoking cessation counselling. Training on smoking cessation needs enforcement during graduate and postgraduate studies as well as in conferences and workshops.

\section{ACKNOWLEDGEMENTS}

The authors acknowledge the physicians of the University Hospital, who participated in the current research for their time and cooperation with the researchers.

\section{CONFLICTS OF INTEREST}

There are no conflicts of interest

\section{REFERENCES}

1. World Health Organization. Tobacco Fact sheet. WHO, 2015. Available at: http://www.who.int/mediacentre/ factsheets/fs339/en/. [Accessed 24 May 2016].

2. Lina M, Mazza R, Borreani C, Brunelli C, Bianchi E, Munarini E, et al. Hospital doctors' smoking behavior and attitude towards smoking cessation interventions for patients: a survey in an Italian Comprehensive Cancer Centre. Tumori 2016; 102:244-251.

3. Zinonos S, Zachariadou T, Zannetos S, Panayiotou AG, Georgiou A. Smoking prevalence and associated risk factors among healthcare professionals in Nicosia general hospital, Cyprus: a cross-sectional study. Tob Induc Dis 2016; 14:14.

4. Abdullah AS, Stillman FA, Yang L, Luo H, Zhang $\mathrm{Z}$, Samet JM. Tobacco use and smoking cessation practices among physicians in developing countries: literature review (1987-2010). Int J Environ Res Public Health 2014; 11:429-455.

5. Al-Turkstani AM, Aba Alkail B, Hegazy AA, Asiri SI. Knowledge, attitude, and practice among primary health-care physicians toward smoking cessation in Makkah, Saudi Arabia. Int J Med Sci Public Health 2016; 5:714-724.
6. Mahfouz AA, Shatoor AS, Al-Ghamdi BR, Hassanein MA, Nahar S, Farheen A, et al. Tobacco Use among Health Care Workers in Southwestern Saudi Arabia. [Internet] BioMed Research International, 2013, Article ID 960292, 5 pages. [Accessed 25 May 2016] Available at: http://dx.doi.org/10.1155/2013/960292.

7. Sabra AA. Smoking attitudes, behaviours and risk perceptions among primary health care personnel in urban Family Medicine Centers in Alexandria. J Egypt Public Health Assoc 2007; 82:43-64.

8. Asid EA. 2010. The effect of physicians' smokingrelated knowledge, attitude, and practices on their smoking cessation counseling, Ateneo de Zamboanga University. Available at: http://som.adzu.edu.ph/ research/pdf/2010-05-26- 094611Smoking among Physicians_in_ZC__Elham_A._Asid.pdf. [Accessed 9 December 2014].

9. IBM Corp. IBM SPSS statistics 20 core system user's guide. USA: IBM Corporation; 2011.

10. Radwan GN, Loffredo CA, Aziz R, Abdel-Aziz N, Labib N. Implementation, barriers and challenges of smoke-free policies in hospitals in Egypt. BMC Res Notes 2012; 5:568.

11. Borgan SM, Jassim G, Marhoon ZA, Almuqamam MA, Ebrahim MA, Soliman PA. Prevalence of tobacco smoking among health-care physicians in Bahrain. BMC Public Health 2014; 14:931

12. Frank E, Segura C. Health practices of Canadian physicians. Can Fam Physician 2009; 55:810-811.

13. Sebo P, Bouvier GM, Goehring C, Künzi B, Bovier PA. Use of tobacco and alcohol by Swiss primary care physicians: a cross-sectional survey. BMC Public Health 2007; 7:5.

14. Wada K, Yoshikawa T, Goto T, Hirai A, Matasushima E, Nakashima $\mathrm{Y}$, et al. Lifestyle habits among physicians working at hospitals in Japan. Japan Med Assoc J 2011; 54:318-324.

15. YoussefRM,Abou-Khatwa SA, Fouad HM. Prevalence of smoking and age of initiation in Alexandria, Egypt East Mediterr Health J 2002; 8:626-637.

16. Nour Eldein H, Mansour NM, Mohamed SF. Knowledge, attitude and practice of family physicians regarding smoking cessation counseling in family practice centers, Suez Canal University, Egypt. J Family Med Prim Care 2013; 2:159-163.

17. Pizzo AM, Chellini E, Grazzini G, Cardone A, 
Badellino F. Italian general practitioners and smoking cessation strategies. Tumori 2003; 89:250-254.

18. Levshin V. Smoking-cessation programme motivates Russian physicians to assist their patients and themselves. Global Health and Environment Monitor, 2004. Available at: http://www.ceche. org/communications/russian-cancer-cen.html. [Accessed 24 May 2016].

19. Ohida T, Sakurai H, Mochizuki Y, Kamal AM, Takemura S, Minowa M, et al. Smoking prevalence and attitudes toward smoking among Japanese physicians. JAMA 2001; 285:2643-2648.

20. Hodgetts G, Broers T, Godwin M. Smoking behaviour, knowledge and attitudes among family medicine physicians and nurses in Bosnia and Herzegovina. BMC Fam Pract 2004; 5:12.

21. Ashton K, Streem D. Cleveland clinic. Center for continuing education. Smoking cessation, 2016. Available at: http://www.clevelandclinicmeded. com/medicalpubs/diseasemanagement/psychiatrypsychology/smoking-cessation/\#top. [Accessed 24 May 2016].

22. Vanphanom S, Morrow M, Phengsavanh A, Hansana V, Phommachanh S, Tomson T. Smoking among Lao medical doctors: challenges and opportunities for tobacco control. Tob Control 2011; 20:144-150.

23. Perrin PC, Merrill RM, Lindsay GB. Patterns of smoking behavior among physicians in Yerevan,
Armenia. BMC Public Health 2006; 6:139.

24. Shi Y, Yu C, Luo A, Huang Y, Warner DO. Perioperative tobacco interventions by Chinese anesthesiologists: practice and attitudes. Anesthesiology 2010; 112:338-346.

25. WHO. The role of health professionals in tobacco control. Geneva: WHO; 2005.

26. McEwen A, West R. Smoking cessation activities by general practitioners and practice nurses. Tob Control 2001; 10:27-32.

27. Youssef RM, Abou-Khatwa SA, Fouad HM. Current and never smokers: differentials in characteristics, knowledge and perceptions. East Mediterr Health J 2003; 9:923-934.

28. Duaso MJ, De Irala J, Canga N. Employee's perceived exposure to environmental tobacco smoke, passive smoking risk beliefs and attitudes towards smoking: a case study in a university setting. Health Educ Res 2006; 21:26-33.

29. Ndiaye M, Hane AA, Ndir M, Ba O, Diop-Dia D, Kandji M, et al. Smoking habits among physicians in Dakar (in French) Rev Pneumol Clin 2001; 57:7-11.

30. Rady M, Sabbour SM. Behavioral risk factors among physicians working at Faculty of Medicine, Ain Shams University. J Egypt Public Health Assoc 1997; 72:233-256. 